\title{
EI SIDA en la literatura latinoamericana: prácticas discursivas e imaginarios \\ identitarios
}

\section{AIDS in Latin-American Literature: Discursive Practices and Imaginaries of Identity}

\section{Andrea Kottow}

Pontificia Universidad Católica de Valparaíso, Chile.

akottow@yahoo.com

Resumen • El artículo propone una revisión del imaginario del SIDA -entendiendo la enfermedad como una práctica discursiva- en tres obras literarias latinoamericanas: Salón de belleza de Mario Bellatín, Loco afán, de Pedro Lemebel y El desbarrancadero, de Fernando Vallejo, con el fin de rastrear las implicancias de trabajar discursivamente con el tópico de una enfermedad de alta sensibilidad social. El poner en circulación el imaginario del SIDA implica impulsar una reflexión acerca de límites, normatividades y poderes, vinculando estas problemáticas con la sexualidad y el deseo. En el espacio de las obras literarias confluyen diversas y complejas líneas discursivas, haciendo del SIDA una plataforma móvil que permite el desplazamiento entre el pensamiento teórico, autobiográfico y estético, funcionando la enfermedad como sustento de un proyecto estético e identitario subversivo.

Palabras clave: SIDA, literatura latinoamericana, imaginario identitario.

Abstract • The present article proposes a revision of AIDS imaginary -understanding the disease as a discursive practice- in three Latin-American works of literature: Salón de belleza, by Mario Bellatín, Loco afán, by Pedro Lemebel, and Fernando Vallejo's El desbarrancadero, looking into the implications of working discursively with the topic of a disease of high social sensibility. Bringing the imaginary of aids to the public sphere leads to a reflection about boundaries, norms and power, linking these issues with sexuality and desire. Diverse and complex lines of discourses converge in the place created by literary works, turning AIDS into a mobile platform that allows for a transfer between theoretical, autobiographical and aesthetic thinking, stating the disease as a foundation of an aesthetic and subversive identity project.

Keywords: AIDS, Latin-American literature, Imaginary of Identity. 
Illness is the night-side of life, a more onerous citizenship. Everyone who is born holds dual citizenship, in the kingdom of the well and in the kingdom of the sick. Although we all prefer to use only the good passport, soone or later each of us is obliged, at least for a spell, to identify ourselves as citizens of that other place.

\section{EL TÓPICO DEL SIDA Y LA METÁFORA VIRAL}

Aunque el tópico del SIDA en tanto enfermedad que amenazaba con convertirse en una pandemia mundial haya ido perdiendo paulatinamente su urgencia, el potencial performativo de la sigla SIDA sigue, sin lugar a dudas, desplegando un gran poder simbólico. El SIDA continúa suscitando una serie de asociaciones, que incluyen tanto determinadas preferencias y prácticas sexuales como un cierto estilo de vida, vinculado al descuido y la irresponsabilidad, así como, eventualmente, a la autorresponsabilidad. En consecuencia, esta patología aún permanece relacionada a ciertos tabúes sociales así como al cuestionamiento de determinadas normas que rigen la convivencia entre los seres humanos.

El temprano estudio de Susan Sontag, AIDS and Its Metaphors de 1988 que, en forma similar a Illness as Metaphor (1978), busca iluminar el fenómeno de la enfermedad con y desde una propuesta ética, evidencia la separación fundamental entre un "nosotros" y los "enfermos", en tanto "otros", constitutiva de la percepción del SIDA. Este distanciamiento discursivo del SIDA tuvo su primera gran manifestación en las patogenias construida para este cuadro: en EE.UU. predominó la idea del SIDA como enfermedad originaria del continente negro; estereotipos que entrelazan una sexualidad negra, excesiva y anómal con ciertas extravagancias morales reviven en esta construcción del origen del SIDA. La teoría haitiana situaba el umbral del SIDA en el turismo sexual que los gay norteamericanos practicarían en Haití, buscando encontrarse con el "falo sagrado" del macho hipersensual haitiano y trayendo a su regreso, en la valija, el virus. En la Unión Soviética corría el rumor que el SIDA sería un arma biológica fabricada por los norteamericanos, que se les habría escapado de las manos, volcándose en contra de sus propios inventores. Esta teoría se extendió a Europa así como a Latinoamérica, en parte como mito urbano y formando parte de teorías conspirativas anti-norteamericanas. El SIDA aparece en todas estas construcciones culturales como una enfermedad de origen exterior que irrumpe en el mundo entendido como propio, sano e intacto, actualizando así un viejo tópico que coloca la proveniencia de una epidemia en el extranjero. El cólera fue llamado enfermedad española, india, asiática, según desde dónde se le percibía y temía.

El SIDA, en su calidad de enfermedad viral, ha sido nominada, y a través de la sustitución del nombre, comparada con la más antigua y feroz de las patologías infecciosas: la peste. Al revisar los discursos sobre la peste llamará la atención que uno de los tópicos

"La enfermedad es el lado nocturno de la vida, una ciudadanía más cara. A todos, al nacer, nos otorgan una doble ciudadanía: la del reino de los sanos, y la del reino de los enfermos. Y aunque preferimos usar el pasaporte bueno, tarde o temprano cada uno de nosotros se ve obligado a identificarse, al menos por un tiempo, como ciudadano $\mathrm{d}$ aquel otro lugar". La enfermedad y sus metáforas, Susan Sontag. Traducción de Mario Muchnik, 1980. centrales que pone en juego esta enfermedad es el de las fronteras. Imperativo número uno es cercar la enfermedad, encerrarla, resguardando de este modo un espacio saludable, libre de ella. Este movimiento de aislar la patología espacialmente se reitera en varios niveles: se debe cercar la patología en el cuerpo del enfermo, pero también se debe sitiar una casa, un barrio, una ciudad o un país que se hayan visto infectados. El Diario del año de la peste de Daniel Defoe de 1722 y La Peste de Camus del año 1947, son obras que, a pesar de la distancia temporal que las separa, muestran las dificultades, concomitantes a la innegable necesidad, de esta medida espacial del sitio.

Las imágenes y metáforas de la infección y lo infeccioso viven desde la erupción de la crisis del SIDA en los años ochenta una nueva coyuntura. Si hasta ese momento, el siglo XX había celebrado los éxitos de bacteriología, inmunología y virología, y se imaginaba la extinción de las enfermedades infecciosas con carácter epidémico, retorna con renovadas fuerzas el miedo frente a virus y bacterias, frente a contagio y contaminación desde la presencia del SIDA. En este proceso, la antigua metáfora de la epidemia y la peste se ha ido entremezclando con diferentes elementos provenientes de diversos ámbitos discursivos: conocimientos médicos, concepciones pseudocientíficas, discursos constituidos en los medios masivos, así como aproximaciones teóricas de los Estudios Culturales marcan en la actualidad los términos de enfermedad infecciosa y SIDA, como también el concepto clave de virus. En estos procesos de traslación de un discurso a otro, algunos elementos centrales se mantienen pero, asimismo, tienen lugar desplazamientos de significación. Esta redistribución de contenidos estructuradores de discursos, como también los cambios de acentuación, se relacionan a su vez con que la medicina, enmarcada en el contexto teórico de las ciencias naturales, procede a un reduccionismo del cuerpo y sus procesos, mientra que la experiencia individual percibe el cuerpo en tanto realidad compleja, estrechamente ligada a conceptos identitarios.

Ruth Mayer y Brigitte Weingart -las dos teóricas alemanas editoras de la antología Virus. Mutationen einer Metapher (Virus. Mutaciones de una metáfora)- destacan en su introducción una serie de implicaciones de la noción "virus", evidenciándose que la distinción entre lo "propio" y lo "extraño" o "ajeno" aparece como una constante en las diversas formas de uso del término:

El tópico de lo viral es evocado cuando se trata de autorizar construcciones fóbicas con la finalidad de imponer medidas que aseguren los límites y las fronteras, sirviendo al mismo tiempo como modelo para proyectos de resistencia y subversivas puestas en escenas de $\mathrm{si}$ mismo (Mayer/Weingart, 2004: 9)2

Habría, siguiendo a Mayer y Weingart, una serie de rasgos compartidos entre los objetos concretos que refieren a imagen y modelo del virus, y sus constructos metafóricos. Los virus se anidan y pasan desapercibidos por el organismo. Recodifican los sistemas de funcionamiento del huésped en pos de utilizarlos para sus propios fines, subvirtiendo así relaciones de poder asimétricas. Los virus mutan y eluden de este modo, muchas veces exitosamente, las medidas dirigidas a combatirlos y desencadenan un proceso de un orden con reglas y lógica propias. Se presentan con una indumentaria mínima, en tanto "paquete de información". Finalmente, el virus encarna un ente de un estatus

"Die Topik des Viralen wird bemüht um phobische Konstruktionen und grenzsichernede Maßnahmen z autorisieren, und dient gleichzietig als Vorlage für Widerstandsprojekte und subversive Selbstinzenierungen." [traducción de la autora] 
poco claro, ni vivo ni inerte. Con estas características, el virus ofrece un modelo para las más diversas negociaciones de límites, en las que se cuestiona la diferenciación entre lo "propio" y lo "ajeno".

La metáfora del virus comenzó a poblar una serie de discursos, tanto literarios como crítico-teóricos y filosóficos en cercanía temporal a la crisis del SIDA de mitades de los años ochenta. A continuación se propone una revisión del tópico del SIDA en algunas obras literarias latinoamericanas -Salón de belleza de Mario Bellatín, Loco afán de Pedro Lemebel y El desbarrancadero de Fernando Vallejo-, con el fin de indagar en los gestos que implican materializar discursivamente esta temática, así como en las estrategias convocadas confrontarse con una patología socialmente sensible y políticamente compleja. El SIDA es entendido en la siguiente lectura como práctica discursiva, que pone en juego imaginarios vinculados a la enfermedad. Llamativo en los textos convocados en esta revisión es una particular forma de entretejerse discurso (auto) biográfico, ficcional y teórico, haciéndose imposible una diferenciación entre los distintos géneros. Pareciera que el SIDA justamente pone en jaque una limitación de realidad y ficción, de enfermedad real y enfermedad literaria, entretejiéndose de manera ineludible la conciencia acerca de una patología que afecta cuerpo individual y cuerpo social, que puebla imaginarios colectivos y alimenta temores sociales, así como sustenta proyectos estéticos subversivos. El presente análisis, entonces, rastrea discursivamente la performática del SIDA en algunos imaginarios textuales latinoamericanos para ver cómo es puesto en circulación en los distintos textos y qué implicancias con relación a conceptos identitarios tiene, precisamente en un subcontinente marcado por la dominancia del sistema patriarcal, la homofobia, el machismo y el doble estándar.

\section{INVERSIÓN DE ESCENA: LA EXCLUSIÓN DE LOS EXCLUIDOS EN SALÓN DE BELLE-}

\section{ZA DE MARIO BELLATIN}

En la pequeña novela de 1994 del mexicano Mario Bellatin, el tópico central vinculado a tema del SIDA es el espacio, convertido en una imagen que problematiza concepciones de belleza y fealdad, libertad y encierro, inclusión y exclusión, así como de vida y muerte. La novela abre con el relato de un narrador en primera persona, un peluquero homosexual que practica el travestismo y la prostitución, centrado en sus experimentaciones con acuarios, que arregla y puebla de peces con la finalidad de adornar el salón de belleza y hacer sentir cómodas y bellas a sus clientas. Así como los peces de colores deben deleitar a los que vienen a embellecerse al salón, éste funciona a su vez, con sus ventanales transparentes, metonímicamente y metafóricamente como un gran acuario, volcado a exhibir belleza hacia la calle. La narración está constituida en base a estas dos líneas temáticas, que se entrelazan, se condicionan y reflejan mutuamente. Los experimentos con diferentes especies de peces, que terminan muriendo por el descuido y desinterés del narrador, son la imagen refleja de salón de belleza, que se convierte en el transcurso del texto en un así llamado "moridero", que acoge a enfermos en la fase final de una enfermedad viral que, aun cuando nunca se nombra, puede ser reconocida con facilidad como SIDA.

La conversión de la peluquería en un lugar de reclutamiento de hombres agonizantes de una enfermedad obviamente infecciosa trae consigo el repudio por parte del vecindario:
La campaña que se desató en el vecindario fue bastante desproporcionada. Cuando la gente quiso quemar el salón tuvo que intervenir la misma policía. Los vecinos afirmaban que aquel lugar era un foco infeccioso, que la peste había ido a instalarse en sus dominios (1999: 35).

El gesto de querer mantener "limpio" y "sano" el entorno, eliminando el moridero, responde a un gesto de exclusión de lo indeseado con fines de mantener un espacio que es percibido como intacto. La novela, sin embargo, visibiliza esta estrategia, invirtiéndola. E narrador establecerá una serie de reglas y normas para el buen funcionamiento del moridero: sólo son aceptados hombres; ni mujeres ni niños pueden instalarse en él. Aquellos que, por la atribuida indefensión, normalmente gozan de determinadas granjerías sociales, en el moridero son rechazados. A su vez, en el lugar no se aceptan medicinas, sean provenientes de la tradición científica occidental o de prácticas alternativas. Como escribe el narrador: "En ese aspecto las reglas del Moridero son inflexibles" (31). Los muchachos u hombres que aún gozan de cierta salud, tampoco reciben acogida:

Yo tenía que sacar la misma vehemencia que mostraba frente a las mujeres que pedían hospedaje y decirles que regresaran meses después. Que no volvieran a tocar las puertas sino hasta cuando sus cuerpos estuvieran irreconocibles. Con achaques y la enfermedad desarrollada. Con esos ojos que yo ya reconocía. Sólo cuando no pudieran más con sus cuerpos les sería permitido entrar al Moridero. Sólo entonces podían aspirar a la categoría de huéspedes. Sólo entonces se ponían en juego las reglas que había ideado para el correcto funcionamiento del salón (52).

El moridero constituye un espacio de reglas que excluye justamente aquellos elementos que se han convertido en el soporte de la sociedad moderna. Si el gran aprecio por la salud y su manutención es uno de los fundamentos de la sociedad burguesa moderna, e moridero invierte la valoración, evidenciándose como un templo de muerte, en el que la mujer -en tanto símbolo de fertilidad y procreación-, la medicina -como el conjunto de prácticas e instituciones que intentan mantener la salud y la vida- y, por último también, el consuelo religioso -en tanto creencia basada en la esperanza y la redención- son excluidos. De este modo, la novela va develando, como su folio negativo, las prácticas de exclusión que estructuran la sociedad moderna, convirtiendo a los excluidos en excluidores.

El teórico de la literatura Thomas Anz muestra en su libro Gesund oder krank? que los términos de salud y enfermedad gozan desde el siglo XVIII un privilegiado lugar en las coordenadas discursivas en las que se trata de negociar asuntos fundamentales relacionados no sólo con la medicina sino asimismo con la ética y estética. En los debates en torno a comportamientos correctos o falsos, los argumentos médicos, basados en la dicotomía de salud y enfermedad, normalidad y desviación, ocupan una fuerza performativa especial dado su efecto dramático. Con la utilización de explicaciones provenientes del ámbito de la medicina, pareciera estarse señalando que lo tratado se relaciona con preguntas existenciales fundamentales. Al introducir, por lo tanto, la dupla enfermo/sano, inevitablemente se pone en juego un código binario a partir del cual se debaten asuntos normativos de nuestra cultura. Un ejemplo claro para este proceso es la forma de problematizar el tema de la masturbación, trabajado en detalle por el historiador de la ciencia Thomas Laqueur en Solitary Sex. A comienzos del siglo XVIII, la práctica masturbatoria pasa de la agenda de curas a la de médicos, dejando, en gran medida, de ser pecaminosa para convertirse en patologizante: 
Medicine had always been something of a moral guide, a kind of ethics of the flesh. That role increased dramatically in the eighteenth century as moral norms became, at least in progressive and and less in divine authority and preached in church, the province of priests or pastors. In this context, it is not surprising that cultural anxieties were translated into disease: diseases of civilization, for example, caused by a variety of bad things - too much luxury, too much novel reading, which stirs up the body and it nerves, or diseases that followed upon too much sexual activity ${ }^{3}$ (2004: 16)

El argumento de Laqueur va más allá de la constatación de que asuntos morales caen paulatinamente bajo el radio de acción de la medicina como efecto de la secularización de la sociedad moderna. El punto central está en mostrar que la masturbación pone en jaque justamente la confianza en el mismo sujeto autónomo y racional que forma la base de la modernidad. La moralidad comienza a imaginarse enraizada en la individualidad, impulsada por el Iluminismo a su adultez. Esta celebración de la autonomía del sujeto requiere, sin embargo, de la confianza en la autodisciplina y la autorregulación. Por lo tanto, lo que Laqueur llama sexo solitario, pone en circulación una amenaza proveniente del secreto que rodea la masturbación, el individualismo máximo que implica así como su estrecha vinculación con la fantasía potencialmente desbordante. Entonces, la masturbación sería el lado oscuro del individualismo moderno, llevando a sus límites precisamente lo que la modernidad considera su centro definitorio.

Pensando en la normatividad de los términos de enfermedad y salud, que regulan los discursos modernos sobre la razón y la sinrazón, la normalidad y la anomalía, lo deseable y deseado, por un lado, y lo indeseable e indeseado, por el otro, Salón de belleza convoca las estrategias puestas en juego cuando se habla del SIDA. El experimento que la novela propone es el de la inversión: los enfermos terminales se organizan y se crean un espacio del cual excluyen a aquellos que se erigen como el soporte de la sociedad moderna, marginando los elementos indeseados. Basado en un sistema racional que pretende la conservación de la vida, la eliminación de la enfermedad y la negación de la muerte, el discurso social dominante evidencia sus lógicas de funcionamiento al ser torcidas en el moridero de Bellatin. Situándose al otro costado de la razón moderna, en un extraño espejismo que rompe con los valores que la sostienen, Bellatin nos entrega una distanciada y fría narración que devela los mecanismos de exclusión de la modernidad.

\section{DICTADURA, NEOLIBERALISMO, HOMOSEXUALIDAD Y TRAVESTISMO EN LOCO}

\section{AFÁN. CRÓNICAS DE SIDARIO DE PEDRO LEMEBEL}

El escritor chileno Pedro Lemebel, quien fundara a finales de los años ochenta junto a Francisco Casas el colectivo artístico "Las yeguas del Apocalipsis", dúo que trabajó con

"La medicina siempre fue algo semejante a una guía moral, una suerte de ética de la carne. Ese papel aumentó considrablemente

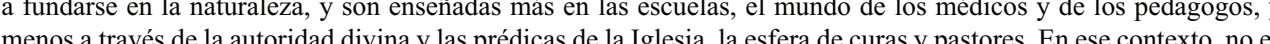
sorprendente que las angustias culturales fueran transformadas en enfermedades; por ejemplo, enfermedades de civilización causadas por una variedad de cosas malas: demasiado lujo; demasiada actividad mental y poco ejercicio, demasiada a fición o demasiada lectura de novels, que a fecta al cuerpo o sus nervios; o enfermedades que provienen de la excesiva actividad sexual" Sexo solitario. Traducción de Marcos Mayer, 2007. performances, happenings y acciones de arte en los que tematizaba tópicos vinculados a la marginalidad social, étnica y sexual con relación a la represión política vivida en la dictadura, publica en 1996 sus crónicas Loco Afán. Crónicas de Sidario. La antología consiste en instantáneas breves y fragmentarias que mayoritariamente giran en torno a la homosexualidad y el SIDA en Chile, concentrándose temporalmente en el período de la así llamada "transición" política. Los y las protagonistas de Lemebel son travestis, transexuales y homosexuales que, dada su condición social precaria, viven en los márgenes de la sociedad. La dictadura agudizó la situación social de homosexuales y travestis. El Chile de Pinochet se presenta en las crónicas de Lemebel como un país militarizado, conservador y católico en el que cualquier atisbo de desviación puede significar persecución, prisión, tortura y/o muerte. Una de las problemáticas que Pedro Lemebel una y otra vez resalta en sus crónicas es la presencia de aquellos elementos que en la transición no han traído la prometida transformación, acusando a los discursos producidos en su interior de dirigir autoritariamente las maneras en las que ideológicamente la oficialidad se hace cargo del pasado dictatorial.

Las crónicas de Lemebel narran de "locas" que se enferman y mueren de SIDA, de sus formas marginales de existencia, de sus muertes y funerales. Tanto política como social y moralmente, las figuras de Lemebel llevan las marcas de la exclusión, por lo que dirige sus textos justamente contra esta triple marginalización. Lemebel desestabiliza permanentemente las concepciones morales prevalentes en Chile. Una de las figuras más utilizadas por el narrador de las crónicas es la del travesti que, como han destacado Baudrillard (1981), Sarduy (1987) y Butler (1990), entre otros, no imita a la mujer, sino propone la puesta en escena de una figura ficticia, hiperbólica que, a través de su inherente exageración, termina cuestionando la naturalidad de la categoría misma de género:

El travesti no copia: simula, pues no hay norma que invite y magnetice la transformación, que decida la metáfora: es más bien la inexistencia del ser mimado lo que constituye el espacio, la región o el soporte de esa simulación, de esa impostura concertada: aparecer que regula una pulsación goyesca: entre la risa y la muerte (Sarduy, 1999: 1267).

El travesti invita a sumergirse en un mundo de las apariencias, de signos puestos en circulación que no circundan un referente, un significado fuera de este universo hecho de significantes en constante proceso de desplazamiento. Baudrillard vincula la figura del travesti a la práctica de la seducción. Ésta se opone radicalmente, así el teórico francés, a la producción. La seducción provoca el revestimiento permanente, funcionando como ente destructor del orden, invirtiendo una y otra vez cualquier fijación de significado, cuestionando, de este modo, el modelo productivo.

Nada le pertenece, excepto las apariencias todos los poderes le escapan, pero hace reversibles todos los signos. [...] Lo único que verdaderamente está en juego se encuentra ahí: en el dominio y la estrategia de las apariencias, contra el poder del ser y de la realidad (2007: 17).

La producción se basa en el contrato, en el intercambio, en la economía; la seducción actúa al margen de toda economía, ensimismándose. Pedro Lemebel pone en juego en sus textos la seducción; sus figuras se mueven en el límite de toda fijación identitaria y todo 
deseo canalizado. Callejeros, errantes, nómades, transexuales, trasvestidos, seductores y seductoras, los personajes escapan de ser subordinados a un modelo productivo.

Respecto a los deslizamientos de los nombres que gay y travestis proponen para burlar el nombre masculino del bautizo, Lemebel escribe:

Como nubes nacaradas de gestos, desprecios y sonrojos, el zoológico gay pareciera fugarse continuamente de la identidad. No tener un solo nombre ni una geografía precisa donde enmarcar su deseo, su pasión, su clandestina errancia por el calendario callejero donde se

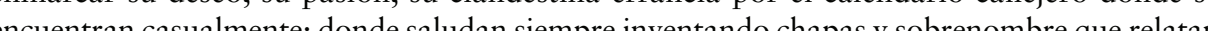
pequeñas crueldades, caricaturas zoomorfas y chistosas ocurrencias (1996: 57).

Este juego patronímico funciona metonímicamente para la escenificación que gays y travestis realizan con relación a su identidad genérica y orientación sexual. Habría un celebración de la indeterminación que sirve de núcleo temático a muchos escritos de Lemebel: seducción por sobre producción, siguiendo a Baudrillard.

El sistema económico neoliberal introducido por la dictadura aparece como un sistema que, por un lado, posibilita la influencia desde afuera, pero que, por el otro lado y en un sentido foucaultiano, trae consigo un disciplinamiento más sutil de los cuerpos y de modelos identitarios. La irrupción de la crisis del SIDA aparece, según Lemebel, como resultado del capitalismo neoliberal y es leído como síntoma de una transformación de las coordenadas en las que se mueve el país: el SIDA desplaza, hace desaparecer a las locas y los homosexuales "de siempre", con su estética local, e instala el ideal de belleza homosexual rubio y musculoso importado de los EE.UU. Para Lemebel, el SIDA entra a Chile junto a modelo homosexual extranjero:

Se puede constatar la metamorfosis de las homosexualidad en el fin de siglo; la desfunción de la loca sarcomida por el SIDA, pero principalmente diezmada por el modelo importa 作 enoltura de esa piel blanca, tan higienica, tan perfumada por el embrujo capitalista. [...] En ese Apolo, en su imberbe mármol, venía cobijado el síndrome de inmuno deficiencia, como si fuera un viajante, un turista que llegó a Chile de paso, y el vino dulce de nuestra sangre lo hizo quedarse $(22-3)$

Es el patrón productivo, exacerbado por la imposición del modelo neoliberal instaurado por la dictadura militar de Augusto Pinochet y continuado por los gobiernos de la transición, el que amenaza la festejada seducción de travestismo y homosexualidad retratada por Lemebel. El nuevo tipo de homosexual estéticamente normado y corporalmente disciplinado, a través de gimnasio y físicoculturismo, se instala junto a la enfermedad de SIDA, desplazando el libre juego de la seducción. El disciplinamiento del cuerpo tiene como su fatal contraparte paradójica el SIDA.

Política, SIDA, travestismo y homosexualidad representan en Loco Afán una unidad indisoluble, que se desarrolla desde el acto escritural. Lemebel no sólo realiza una observación histórica de los oscuros años de la dictadura, sino también describe el tiempo de la transición como una desilusionante democracia aparente que sólo logra dejar atrás lenta y parcialmente las coordenadas estrechas impuestas por la dictadura y marcadas por un sistema neoliberal únicamente interesado en los flujos productivos del mercado, marginando los juegos solipsistas de la seducción.
En las crónicas de Lemebel el juego con la verosimilitud es fundamental: autobiografía, comentario histórico y político e hipérbole estética se entremezclan en el imaginario que el narrador de los textos despliega con relación al tópico del SIDA. Éste se convierte en una plataforma múltiple que permite deslizarse entre realidad y ficción, escapando de la posibilidad de hacer un distingo claro entre ambos.

\section{EXORCISMO Y VIOLENCIA EN EL DESBARRANCADERO DE FERNANDO VALLEJO}

El enfant terrible de la literatura colombiana contemporánea es el novelista Fernando Vallejo, famoso y temido no sólo por su homosexualidad vivida abiertamente, sino también por sus crudas declaraciones acerca de la sociedad colombiana. En el año 2001 publica $E l$ desbarrancadero, novela que gira en torno a la homosexualidad del narrador en primera persona y de su convaleciente hermano, enfermo de SIDA. El narrador, quien vive en México, regresa a su casa paterna en Medellín para cuidar a su hermano y acompañarlo hasta la muerte. El texto de Vallejo se dirige contra todos y todo lo que puede ser subsumido bajo los términos de autoridad y moral: el Estado, la Iglesia, la familia, la maternidad no sólo son ironizados sino también insultados y directamente desvalorizados. Descripciones minuciosas de los síntomas patológicos del hermano, en los que se cita hasta la ridiculez el lenguaje cientificista de la medicina y la biología, se combinan en la novela con ataques a todo tipo de institucionalidad reguladora.

Pero de veras era la candidiasis la que le producía las ulceraciones? No sería más bien un leucoplaquia? O el sarcoma de Kaposi, que sin lugar a dudas tenía a juzgar por las manchas del cuerpo y de la cara? Y podía yo jurar que la diarrea se la causaba la criptosporidiosis? Porque también podía causársela una bacteria... O un hongo... (2003: 186).

La patria colombiana es descrita como un gran basural caótico en el que la corrupción de los políticos es comparable a la de los narcotraficantes y en el que el pueblo, embrutecido e insensible, pareciera no tener otro afán que reproducirse y aumentar así la pobreza. El SIDA no sólo se convierte en la enfermedad que le quita al narrador su querido hermano, sino que se constituye como una metáfora de la vida y de la sociedad. La novela se asemeja a un rezo, que en lugar de estar dirigido a Dios, le rinde tributo a la muerte. El texto invierte así cualquier imagen que potencialmente pudiese poseer algún carácter modélico en Latinoamérica, constituyéndose desde las zonas marginales tabuizadas de la pobreza, la homosexualidad, la enfermedad, la muerte y la impiedad. Los blancos específicos de la novela son los políticos, la religión -encarnada por el papa del momento, Juan Pablo Segundo- la familia -cuyo símbolo, la madre, es invertida en el modelo contrario de la prostituta- y la patria, Colombia.

El teórico norteamericano Sander Gilman ha destacado que la enfermedad se convierte en uno de los continentes para la estructura básica de los estereotipos encarnados por la fantasía inherente y universal de la madre "maléfica", opuesta a la madre "benévola". Mientras que esta última puede ser controlada, la "mala madre" escapa a los controles del individuo. En estas fantasías internalizadas, enraizadas en la fase pre-edípica del desarrollo humano, la mala madre llega a asociarse a todo lo que refleja nuestro miedo frente al caos, densificándose de este modo todo lo disruptivo en ciertos nudos simbólicos. Sin embargo, 
según la reflexión de Gilman, esta estructura dicotómica que pretende alejar toda amenaza de lo que es sentido como "yo" y "propio" se ve constantemente amenazada:

But we all are at risk -we will all be ill, will fail, will die? What happens, however, when our sense of ourselves as 'the patient', of ourselves as existing on the wrong side of the margin between the healthy and the diseased, becomes alien to our definition of self? ${ }^{5}(1988: 4-5)$

La literatura y el arte se convierten en un espacio que serviría al exorcismo de las imaginaciones asociadas a la mala madre, una estrategia para salvaguardar la integridad del yo y protegerlo de la amenaza acechante del caos. Gilman observa que las imágenes convocadas en construcciones en las que se produce la identificación con lo amenazado, con lo enfermo, en tanto el "yo" se autopercibe como formando parte de los que se encuentran expuestos al riesgo del caos, son más convulsas y complejas que aquellas destinadas a posicionar el riesgo en el "otro". En cuanto a la identificación con las fantasías colectivas vinculadas a enfermedades, ésta se relaciona con una tentativa, siempre precaria, de comprensión de nuestra propia fragilidad y mortalidad.

El texto de Vallejo exorciza las fantasías en torno a patología y muerte, identificándose con el caos, despreciando la salud y la medicina. A la sífilis, enfermedad de alguna manera precursora del SIDA, el narrador de El desbarrancadero la canta un himno de admiración:

Bailarina brillante en campo oscuro, espigada, lujuriosa, espiroqueta pálida, con tu ceñido vestido de plata y tu cuerpo de mujer, qué bella te ves bailándome la danza de los siete velos e igual número de pecados capitales, retorciéndote como un tirabuzón bajo mi microscopio (50)!

Al identificar la síflis con Salomé, una de las figuras femeninas bíblicas más retratadas en el arte, erige la enfermedad en tanto símbolo de la seducción. En la Salomé de Oscar Wilde, una de las plasmaciones literarias más célebres de la tradicional Salomé, la premonición de la muerte se anuncia con la presencia amenazadora de una luna que parece teñirse de la sangre venidera. Vallejo retoma en su novela el símbolo de la luna como anuncio de la fatalidad:

Esa tarde en el balcón, mirando el vacío, vi ponerse el sol estúpido por entre las montañas, y lir de entre las món na la estúpida luna. En la oscuridad, de súbito, al unísono, se encen salir de en lo lo dieron tras la luna los infitos focos de los infinitos barrios de la ciudad, y sumando su luz a ceniza, aleteando, descendía sobre Medellín y mi casa el gran pájaro negro (101).

Mientras que el espíritu decadente de finales del siglo XIX lograba estetizar los fenómenos de enfermedad y muerte -ahí el guiño intertextual a la Salomé de Wilde- en la novela de Vallejo, enfermedad y muerte son hechos vaciados de sentido, fenómenos que simbolizan la destrucción y desestructuración social. El narrador habla desde la enfermedad y la muerte, evidenciándose la imposibilidad de protegerse de ellas y asumiendo, entendido en el sentido que Gilman plantea, el caos concomitante. La novela se constituye a partir de la asunción de ese desmoronamiento; metonímicamente la enfermedad de su hermano es

"Pero todos estamos en riesgo— enfermaremos, nos deterioraremos, moriremos. Sin embargo, "¿qué sucede cuando la noción de nosotros mismos como "pacientes", estando en el lado equivocado de la división entre los sanos y los enfermos, sea más importante que nuestra definición del ser?" [Traducción del texto original en Inglés] sólo un signo de la muerte que se vuelca sobre toda la casa que, a su vez, es sólo un punto en la mortífera ciudad de Medellín, urbe que representa extensivamente a Colombia, país contenedor de todo lo malo de Latinoamérica.

En El desbarrancadero, el que habla no se protege por vía de su acto escritural de las fuerzas amenazadoras del impulso de vida; más bien por el contrario, se funde con ellas. En la auto-descripción del narrador se produce su des-identificación:

Yo no soy hijo de nadie. No conozco la paternidad ni la maternidad de ninguna. Yo soy hijo de mí mismo, de mi espíritu, pero como el espíritu es una elucubración de filósofos confundidores, entonces haga de cuenta usted un ventarrón, un ventarrón del campo que va por e terrenal sin ton ni son ni rumbo levantando tierra y polvo y ahuyentando pollos (49).

Sin genealogía ni sustancias identificables, el narrador se parece a la enfermedad que circunda en su escritura. Como un virus, la escritura destruye, des-subjetiviza, desbarrancando todo lo que se le cruce en el camino.

\section{IMAGINARIOS PATOLÓGICOS: ¿LA DES-METAFORIZACIÓN DEL SIDA?}

La revisión de los textos de Bellatin, Lemebel y Vallejo que trabajan con el imaginario de SIDA muestran cómo tratar discursivamente esta enfermedad se ha vinculado con la reflexión acerca de normatividades, límites y poder. La enfermedad, asociada a determinados comportamientos y prácticas sexuales, sirve a los autores estudiados para hacer visibles mecanismos de exclusión ciertas formas de vivenciar la sexualidad, el deseo y el goce. Bellatin construye en su Salón de belleza una inversión del gesto de exclusión, dominante en el tratamiento del tópico de la enfermedad, especialmente de las que tienen carácter infeccioso y que son asociadas a grupos y prácticas minoritarias. Lemebel focaliza en sus crónicas la escena de la homosexualidad, el travestismo y el SIDA en la época de la dictadura y transición chilena, para mostrar las represiones vividas y la paradójica entrada de la enfermedad a Chile, producto del sistema neoliberal instituido por el régimen militar En último lugar, Vallejo exorciza todo tipo de odios y violencias a partir del imaginario del SIDA, posicionándose constantemente en opiniones y argumentos políticamente incorrectos, para ir develando la corrupción así como la hipocresía del contexto colombiano. En todos los textos comentados, se observa una politización del discurso que se hace cargo del SIDA, señalándose estrategias de identificación, conceptos identitarios y normatividades sociales y morales. En las obras revisadas se evidencia la fusión de discursos (auto) biográficos, teóricos y estéticos, haciendo de esta forma del SIDA un tópico que funciona como plataforma múltiple y móvil que permite la puesta en circulación de diversos discursos. Los imaginarios que las obras constituyen son de carácter complejo; están construidos a base de elementos diversos y heterogéneos, funcionando sobre variados niveles: comentan hechos sociales, históricos, políticos, subvierten imaginarios colectivos dominantes, simbolizan una patología que a su vez pone en juego una amplia gama de metaforizaciones.

Desde el texto de Bellatin, del año 1994, hasta el de Vallejo, publicado en 2003, transcurren casi diez años: podría preguntarse si acaso pueden identificarse transformaciones en el tratamiento literario del SIDA, tomando en cuenta también la creciente efectividad de la así llamada terapia HAART (Highly Active Antiretroviral Therapy), introducida a 
mediados de los años noventa, que, si bien no logra erradicar el virus del cuerpo del enfermo, sí prolonga considerablemente las expectativas de vida. En los tres textos estudiados se evidencia una identificación de la patología del SIDA con una sentencia de muerte, resguardando las maneras heterogéneas que tiene cada una de las obras en su aproximación a dicha superposición de SIDA y muerte. En las obras revisadas no se trata tanto de trabajar con el tópico del vivir con SIDA como del morir de SIDA, vinculando, en todos los casos, el síndrome con el ser homosexual y las represiones identitarias que esta forma de desear y gozar llevan consigo en las normatividades sociales situadas en Latinoamérica.

Susan Sontag, en su ya clásico trabajo Illness as Metaphor, revisa el imaginario colectivo acerca de dos enfermedades que han suscitado de forma especialmente fructífera metaforizaciones y fantasías en el arte, la literatura y la imaginación común: la tuberculosis y el cáncer. Lo que comparten estas dos enfermedades, dominantes en su capacidad metaforizadora respectivamente en los siglos XIX y XX, es ser consideradas intratables, caprichosas, incomprendidas y, consecuentemente, mortales. Sontag muestra en el caso de la tuberculosis que su potencial de generar fantasías y metáforas se pierde una vez encontrada la cura, pronosticándole el mismo destino al cáncer, que dejará de ser considerad un ladrón insidioso de la vida cuando su etiología se clarifique y su tratamiento se haga efectivo. La fuerza simbólica de las enfermedades radica, por lo tanto, en su misterio y su vinculación con la muerte.

¿Qué sucede con las mitologizaciones en torno al SIDA? Sorprendentemente, casi habría que decir, los textos revisados en este trabajo no evidencian grandes cambios en su tratamiento de la patología: como se ha dicho más arriba, la asociación del SIDA con la muerte no ha perdido, hasta la última obra trabajada acá, su fuerza simbólica. Sin embargo, el tiempo sigue transcurriendo. Sin entrar en un análisis más detallado, quiero cerrar estas reflexiones con una alusión a la "novela trash" -así el subtítulo de La ansiedad-del escritor argentino Daniel Link, un texto construido en su totalidad en formato de mensajes de emai y diálogos escritos a modo de chat virtuales. En esta novela, del año 2004, el protagonista es Internet, y la trama indaga en las formas en que la tecnología va transformando nuestras relaciones, sean éstas amistosas, amorosas, erótico-sexuales o comunicacionales. En el centro del texto se encuentra una historia de amor entre dos hombres, que da unidad a la gran cantidad de retazos de diálogos, fragmentos de textos y cartas que conforman el cuerpo textual. Como un dato más, igualado por el formato virtual que unifica todo lo que integra la novela, el "Laboratorio de Citometría y Biología Molecular" envía con cierta regularidad a uno de los protagonistas sus resultados médicos referentes a la presencia y cuantificación de la carga viral plasmática VIH-1. En el diálogo que el personaje Manuel Spitz lleva con su enamorado, con sus amigos así como con anónimos desconocido del mundo indefinido del chat, su condición no es digna de mención. Hará unas poquísimas alusiones a ella, sin nombrarla ni tampoco darle demasiada importancia. Es un detalle más de su vida, de mucho menor relevancia y urgencia que su vida amorosa y sexual. Pareciera que el dato (un dato más en un mundo dominado por justamente esto: datos) de ser VIH positivo ha pasado de ser un problema existencial a conformar una tensión que se subordina al tema farmacológico. La única referencia explícita que se tiene al Virus de Inmunodeficiencia en esta novela es la presencia de estos protocolos químicos que Spitz recibe por parte del laboratorio.

Siguiendo a Sontag, podríamos aventurar la hipótesis que el SIDA ha ido dejando de ser una plataforma metafórica potente en el transcurso de los últimos años justamente porque el halo de misterio que desde mediados de los ochenta hasta fines de los años noventa lo rodeaba, ha ido disipándose. La enfermedad se ha heterogeneizado, dejando de ser una enfermedad particular de determinados grupos de riesgo, lo que ha implicado a su vez su feminización. Las cifras de contagio no siguen creciendo -exceptuando el caso de África, donde la enfermedad merece un acercamiento propio, que se haga cargo de las especificidades y magnitudes del problema en este continente- y las terapias se hacen cada vez más efectivas. Esta desmitologización del SIDA mengua su potencial simbólico y la retira paulatinamente del escenario metafórico del arte y la literatura.

Otras imágenes vinculadas al cuerpo y sus simbolizaciones se están abriendo paso desde algunos años en el campo de la cultura y sus manifestaciones artísticas: aquéllas vinculadas a la medicina y experimentación genética. Hombres-máquinas, seres clonados, ciborg, androides, así como cuerpos humanos genética o mecánicamente manipulados rebasan en sus apariciones el género que tradicionalmente han estado poblando, el de la Ciencia Ficción. La problemática nueva que parece estar introduciéndose en estas novelas, muchas veces distópicas, es la vinculación de la manipulación del cuerpo con una necesaria transformación de la concepción de vida y muerte, así como de los procesos físicos de enfermedad, deterioro y vejez. Sin adentrarme en estos momentos en el gran campo de exploración que esta metáfora puede abrir, sí novelas como The Body de Hanif Kureishi del año 2002, Never let me go de Kuzuo Ishiguro, publicada en 2005, y La possibilité d'une île de Michel Houellebecq, también de 2005, parecieran indicar que una de las metáforas fuertes relacionadas al tópico de salud y enfermedad y vida y muerte se genera en estos tiempos en el entrecruce entre medicina y tecnología ${ }^{6}$.

\section{REFERENCIAS}

Anz, Thomas. (1989). Gesund oder krank? Medizin, Moral und Ästhetik in der deutschen Gegenwartsliteratur. Stuttgart: Metzler.

Baudrillard, Jean. (2007). De la seducción. Trad. De Elena Benarroch. Madrid: Cátedra.

Bellatin, Mario. (1999 [1994]). Salón de belleza. México: Tusquets.

Butler, Judith. (1990). Gender Trouble. Feminism and the Subversion of Identity. New York, London: Routledge.

Franco, Jean. (2003). Decadencia y caída de la ciudad letrada. Madrid: Debate.

Gilman, Sandre. (1988). Disease and Representation. Images of Illness from Madness to AIDS. Ithaca, London: Cornell University Press.

Laqueur, Thomas W. (2004). Solitary Sex. A Cultural History of Masturbation. New York: Zone Books.

Lemebel, Pedro. (1996). Loco afán. Crónicas de sidario. Santiago de Chile: LOM. Link, Daniel. (2004). La ansiedad. Novela trash. Buenos Aires: El cuenco de plata

Mayer, Ruth y Brigitte Weingart (eds.). (2004). Virus! Mutationen einer Metapher. Bielefeld: transcript Verlag.

Nordgren, Anders. (2003). "Metaphors in Behavioral Genetic". Theoretical Medicine 24 59-77.

6 Ilustrativo para el interés simbólico en torno al tema de la genética es, a su vez, la atención que ha provocado por parte de las humanidades médicas. El articulo "Metaphors in Behavioral Genetics" (2003) de Anders Nordgren revisa las metáforas con las que se circunscribe el discurso genético en textos científicos, resaltando imágenes vinculadas a la computación y al mundo tecnológico, como los de código y programa. 
Richard, Nelly (ed.). (2000). Politicas y estéticas de la memoria. Santiago de Chile: Cuarto Propio.

Richard, Nelly y Alberto Moreiras (eds.). (2001). Pensar en la postdictadura. Santiago de Chile: Cuarto Propio.

Sarduy, Severo. (1999 [1993]). "Pájaros en la playa” en Obra completa, Tomo I. Eds. Gustavo Guerrero y François Wahl. Pp. 915-1005. Madrid, Barcelona, Lisboa, París, México, Buenos Aires, São Paulo, Lima, Guatemala, San José: ALLCA XX.

—. (1999 [1982]). "La simulación" en Obra completa, Tomo II. Eds. Gustavo Guerrero y François Wahl. Madrid, Barcelona, Lisboa, París, México, Buenos Aires, São Paulo, Lima, Guatemala, San José: ALLCA XX.

Sontag, Susan. (2002 [1987], [1988]). Illness as Metaphor and AIDS and its Metaphors. London: Penguin Books.

Vallejo, Fernando. (2003). El desbarrancadero. Buenos Aires: Alfaguara.

Recepción: miércoles 11 de noviembre de 2009 Aceptación: jueves 14 de enero de 2010 